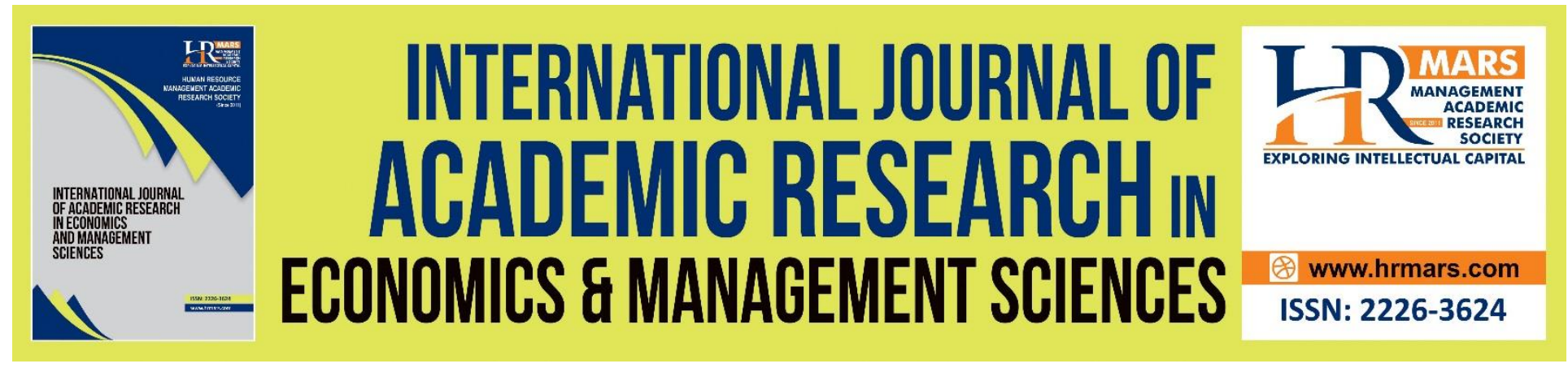

\title{
Assessment of Predictors that Influence Parents' Satisfaction towards Private Kindergartens: A SERVQUAL Analysis
}

Angelia Ling, Siti Aisyah Ya'kob, Irma Yazreen Md Yusoff, and Nor Afiza Abu Bakar

To Link this Article: http://dx.doi.org/10.6007/IJAREMS/v8-i4/6686

DOI:10.6007/IJAREMS/v8-i4/6686

Received: 13 October 2019, Revised: 29 November 2019, Accepted: 11 December 2019

Published Online: 26 December 2019

In-Text Citation: (Ling, Ya'kob, Yusoff, and Bakar, 2019)

To Cite this Article: Ling, A., Ya'kob, S. A., Yusoff, I. Y. M., and Bakar, N. A. A. (2019). Assessment of Predictors that Influence Parents' Satisfaction towards Private Kindergartens: A SERVQUAL Analysis. International Journal of Academic Research in Economics and Management Sciences, 8(4), 1-14.

Copyright: (C) 2019 The Author(s)

Published by Human Resource Management Academic Research Society (www.hrmars.com)

This article is published under the Creative Commons Attribution (CC BY 4.0) license. Anyone may reproduce, distribute, translate and create derivative works of this article (for both commercial and non-commercial purposes), subject to full attribution to the original publication and authors. The full terms of this license may be seen at: http://creativecommons.org/licences/by/4.0/legalcode

Vol. 8, No. 4, 2019, Pg. 1 - 14

http://hrmars.com/index.php/pages/detail/IJAREMS

JOURNAL HOMEPAGE

Full Terms \& Conditions of access and use can be found at http://hrmars.com/index.php/pages/detail/publication-ethics 


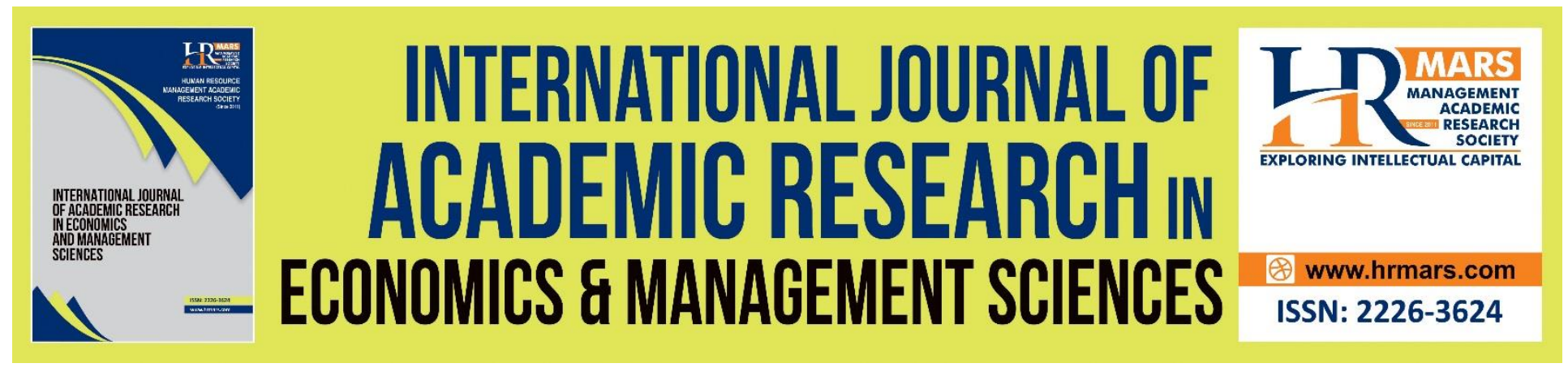

\title{
Assessment of Predictors that Influence Parents' Satisfaction towards Private Kindergartens: A SERVQUAL Analysis
}

\section{Angelia Ling, Siti Aisyah Ya'kob, Irma Yazreen Md Yusoff, and Nor Afiza Abu Bakar}

Faculty of Economics and Business, Universiti Malaysia Sarawak, Malaysia.

Email: ysaisyah@unimas.my

\begin{abstract}
This study examines parents' satisfaction towards the service quality of private kindergarten in Kuching. Five dimensions in SERVQUAL are applied as the indicators that influence parents' satisfaction. In total 400 questionnaires were distributed to the respondents. Data collected is analyzed by employing descriptive statistics, reliability analysis, correlation and multiple linear regressions. In this research, the Pearson Correlation shows the five SERVQUAL dimensions have a positive and relationship on parents' satisfaction. In order to identify the best predictor that contributes to parents' satisfaction, the multiple linear regressions are used to predict the impact on the five SERVQUAL dimensions on parents' satisfaction. In a nutshell, responsiveness is the most significant and dominant dimension that influences parents' satisfaction. The results suggest the private kindergarten operators emphasize more on ensuring continuous communication with parents. Teachers play an important role as they should regularly tell and ask parents in order to understand each child's situation. Teachers are suggested to promptly respond to children's needs and make efforts to address them.
\end{abstract}

Keywords: SERVQUAL Model, Service Quality, Early Childhood, Parents' Satisfaction

\section{Introduction}

Pre-school is known as a kindergarten, a program for early childhood education for children aged four to six. There are about 3000 kindergartens in Sarawak, most of which are managed by the government (Pre-school, 2018). This includes more than 1,000 in the education department and another 1000 in the community development department. There is also a large number of registered private kindergartens operate in residential areas in Sarawak. All public and private kindergartens must implement the National Pre-school Curriculum standard set out in the 1996 National Education Act. The National Pre-school Curriculum is based on the national principles of Malaysia (known as Rukun Negara) and the National Education Philosophy to seek at developing children's social capabilities, intellectual ability, physical attributes, spiritual 
expertise and aesthetic values in children (Pre-school, 2018). The country has the quality standard of education the kindergartens offer via the National Pre-school Quality Standard. The quality involved pre-school management, teachers, implementation of national pre-school curriculum standard, parent-school interaction as well as safety, health and nutrition (Menon, 2016).

This study intends to investigate the dimensions of service quality that affect parents' satisfaction towards private kindergarten in Kuching in Sarawak, Malaysia. Service quality in the education sector is an important aspect and has received considerable attention. In early childhood education, parents represent consumers and partners. They make an important decision in selecting schools for their children, which lay the foundation for their children's education (Cryer \& Burchinal, 1997; Woodhead, 1996). Today's parents come up with the option of providing the best education for their children. On the one hand, parents are more aware of the service quality level they obtained. On the other hand, service providers pay more attention to the level of the service they provide to parents as that reflects their reputation.

The outcomes of this study may provide data from a local context on parents' views, beliefs, and thoughts. This study has useful input that may deliver significant information on parents' satisfaction with the service quality of the private kindergarten. Overall, this study is also useful for a better understanding of how to change and what parents need to be happy with the services offered by private kindergartens. Consequently, this study aims to:

a. examine the relationship between reliability, tangibles, responsiveness, assurance and empathy on parents' satisfaction towards private kindergartens in Kuching city and,

b. identify the most influential dimension that affects parents' satisfaction towards private kindergartens in Kuching city.

\section{Literature Review}

The SERVQUAL model was developed by Parasuraman et al. (1988) and has become a standard method for service quality measurements. SERVQUAL uses 22 Likert-scale items that focus on the differences between consumer expectations of the service and the consumer's perception of service performance (Parasuraman et al., 1988). Baki, Basfirinci, Murat and Cilingir (2009) stated that perhaps the quality of service is being built based on the perceptions of the customer and the desired quality. Parasuraman et al. (1991) claimed that SERVQUAL can be adapted to various industries. They are supported by Davies, Baron, Gear, and Read (1999) who viewed the SERVQUAL as the ubiquity instrument that can be utilized universally. Meesala and Paul (2018) also mentioned that the SERVQUAL framework had evaluated service quality across multiple sectors such as banking, hospitality, internet marketing, insurance, restaurants, and so on. SERVQUAL is a popular tool and often used by managers because it combines flexibility and eases to apply (Asubonteng, Mccleary, \& Swan, 1996). Hence, SERVQUAL can be considered as the standardized instrument and prioritized by the organizations in service quality and customer satisfaction measurement. Figure 1 illustrates the proposed conceptual framework for assessing the quality of service at the level of satisfaction of parents towards private kindergartens. 


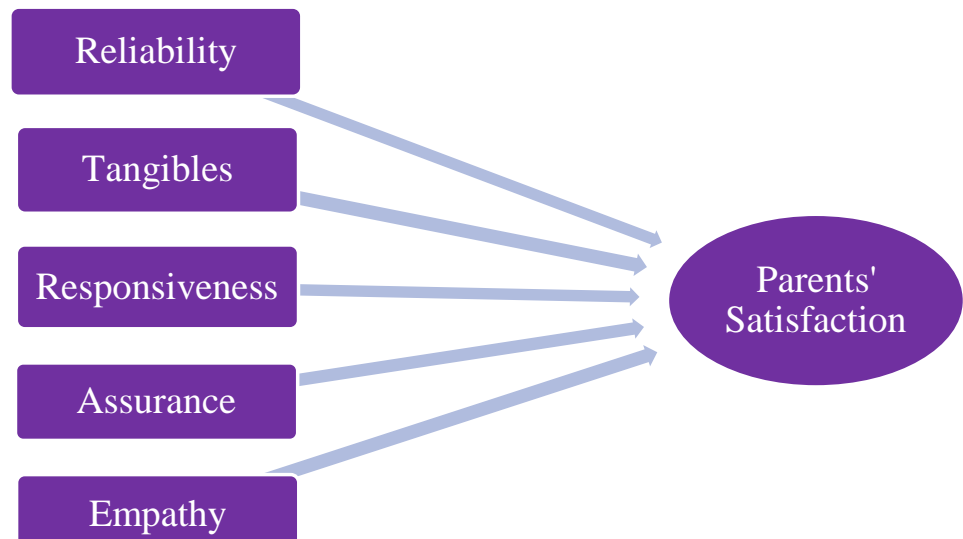

Figure 1

Theoretical Framework of Parents' Satisfaction Level Using SERVQUAL Model

Sources: Parasuraman et al. (1988)

\section{Parents' Satisfaction}

Customer satisfaction refers to the result of cognitive and emotional assessments in which some of the comparison measures compared to actual perceived performance (Lin, 2003). Satisfaction or dissatisfaction depends on whether the service offered meets the customer's standards (Gerpott et al., 2001) and is determined by the fulfillment of the needs (Hill, Roche \& Allen, 2007). Customer satisfaction has been seen as influencing the repurchase desires and actions, while dissatisfaction turns unhappy customers to other companies' offerings (Kolter \& Armstrong, 2012). Through contrasting perceived product or service quality and expectations, Kotler and Keller (2016) provide a broad definition of satisfaction by describing a sense of pleasure or dissatisfaction. In order to create customer satisfaction, it is necessary to meet the needs of parents. Salisbury et al. (1997) report improving parents' satisfaction is a way to improve the school's performance. Parents' satisfaction could be measured by using a subjective approach which is assessing the primary data obtained from respondents who are suitable to respond through a questionnaire (Vij \& Bedi, 2016) - i.e. parents who send their children to private kindergarten. This paper measures parents' satisfaction using a subjective approach defined by four indicators - i.e. decision to visit the kindergarten, the choice to leave a child at the kindergarten, do the right thing to leave the child in the kindergarten, and child's enjoyable experience. The four indicators are originated from Kim (2014).

Reliability

Reliability refers to employees' capability of delivering dedicated services in a timely and accurate manner (Parasuraman et al., 1988). To provide excellent service performance, reliability is always considered as one of the important components in service quality (Parasuraman et al., 1988; 1991). Reliability is seen as a vital aspect of service that contributes to a greater degree of a disappointment than satisfaction. Previous empirical studies have proven that reliability has a significant positive relationship with customer satisfaction (Amin \& Isa, 2008; Al-Tamimi \& Al- 
Amiri, 2003; Incesu \& Asikgil, 2012; Parasuraman et al., 1988; 1991). Previous studies in various sectors assess reliability through measures such as deliver timely service, provide accurate service, as well as respond promptly and politely (Meesala \& Paul; 2018). There is no exception to the importance of the reliability dimension in the education sector. Parents valued the most when pre-schools can provide healthy and safe meals, promise things can complete on schedule, help children to resolve problems and faithfully inform parents about pre-school education information (Chen \& Childhood, 2016). This paper assesses the reliability dimension using six variables originated from Kim (2014) which include scheduled services, records and notices accuracy, emergency situation response, observing vehicles that transport children, the prescribed services and operation time and observing rules. Based on the explanation above, it is hypothesized that:

$\mathrm{H} 1$ : There is a significant and positive relationship between reliability and parents' satisfaction.

\section{Tangibles}

Tangibles are identified as the physical appearance of the organization including facilities, equipment as well as the appearance of personnel (Parasuraman et al., 1988). This dimension is commonly used to relate the physical properties of the service providers, the tools utilized to provide service and also the appearance of the employees. Empirical studies have proven that tangible has a significant positive relationship on customer satisfaction (Al-Borie \& Damanhouri, 2013; Incesu \& Asikgil, 2012; Zakaria, Hussin, Batau \& Zakaria, 2010). Physical facilities and other features of the physical environment show a significant impact on fulfilling first impressions (Vaz \& Mansori, 2013). Researchers have various interpretations of the tangibles dimension in view of the nature of the firm "s industry. In a service-based industry, tangibles are reflected through the employees' appearance, convenient locations and modern equipment and technology (AlBorie \& Damanhouri, 2013). This paper assesses tangibles across seven variables from Kim (2014) which includes kindergarten's various types of room facility, indoor equipment and teaching aids, outdoor playground, cleanliness, and safety equipment. Based on the explanation above, it is hypothesized that:

$\mathrm{H} 2$ : There is a significant and positive relationship between tangibles and parents' satisfaction.

\section{Responsiveness}

The responsiveness dimension describes the person who is willing to help the customers and provide timely service (Murali, Pugazhendhi, \& Muralidharan, 2016). In an earlier study, customers expect employees can complete inaccurate execution time and responding to the customer request when it is needed (Parasuraman et al., 1991; Zeithaml et al., 1988). The latter study discovers customers are highly concerned about the time it takes to respond and deliver a service as well as not getting bored with answering customer questions when problems arise (Suki \& Lian, 2011). The key to the success is the employees' attitude towards customers, the correct communication with the customers and the accurate service delivery (Meesala \& Paul, 2018). The responsiveness dimension has a direct influence on customer satisfaction (Kuo, Tsai, Lu, \&Chang, 2016). The responsiveness dimension scored the highest negative because the customers did not receive the service promptly (Butt \& de Run, 2010). Mosahab and Mahamad (2010) reflected that respondents' views to make it clear that the responsiveness dimension is 
the most critical dimensions of education services. Responsiveness also has a significant influence on the satisfaction level is due to receiving constructive feedback in a reasonable amount of time. This paper assesses the responsiveness dimension through five variables which includes prompt response to the need of children and effort to address them, be proactive and responsible in taking care of and educating the children, regular interaction to recognize parents needs and to share information about children, respond proactively to parents' requests and concerns, and respond correctly and inform the guardian promptly if the child is injured or sick. Based on the explanation above, it is hypothesized that:

H3: There is a significant and positive relationship between responsiveness and parents' satisfaction.

\section{Assurance}

Assurance reflects employees' basic knowledge, politeness and the ability to demonstrate confidence and trust (Parasuraman et al., 1991). Customers value their willingness and courtesy to serve them (Vaz \& Mansori, 2013). Assurance is the most critical factor to explain satisfaction in Hasan, llias, Rahman, and Razak (2009) work. When customers are satisfied with the organizations or offerings, trust should be higher (Flavian, Guinaliu, \& Gurrea, 2006). Assurance is associated with satisfaction, which means that students in learning institutions are focused on learning, politeness, and the ability to inspire trust and confidence (Soutar, 2016). In the healthcare sector, assurance has a significant impact on patients by explaining that employees usually provide their clients with medical treatment, data sharing and clear medical understanding (Suki \& Lian, 2011). Similar to the education sector, assurance has a significant impact on the parent's satisfaction (Incesu \& Asikgil, 2012). This study indicated that parents attach great importance to the courtesy and trust of employees and teachers. Their finding is consistent with Chen and Childhood (2016) who point out that assurance attaches the importance to the quality of service because pre-schools are capable of providing a good learning environment, excellent staff service attitude, excellent teachers' competence and the ability of staff to respond to crises. This paper assesses assurance through Kim's (2014) four variables - i.e. teachers' knowledge and education, personality and appropriate refinement, the right attitude to deal with children, and trustworthy and reliable in the use of the facility. Based on the explanation above, it is hypothesized that:

H4: There is a significant and positive relationship between assurance and parents' satisfaction.

Empathy

Empathy is instilled when the organization pays its affectionate, unique attention and understands the needs of its customers (Parasuraman et al., 1985). Empathy features include providing a convenient hour of collaboration, learning about customer's specific requirement and providing personalized attention to customers. Previous studies ascertain that there is a significant positive correlation between empathy and satisfaction (Hasan, Ilias, Rahman, \& Razak, 2009). Empathy plays a key role in satisfying clients as it can communicate care and understanding through staff interpersonal skills as well as client-friendly policies and procedures (Hasan et al., 2009). Hasan et al. (2009) found formal and informal contacts with instructors make 
students satisfied with their experience at the school. Parents expect their children to interact sufficiently with their teachers to satisfy the children (Kim, 2014). Incesu and Asikgil (2012) reported there is a significant impact between empathy and parents' satisfaction. Empathy measured through care and personal attention (Kim, 2014) can have an impact on satisfaction as customers believe that the organization is trying to individualize services based on their personal needs (Vaz \& Mansori, 2013). It could be predicted that the student-instructor relationship may affect the satisfaction level. This paper uses four variables to measure empathy - i.e. pay sufficient attention to each child, seriously consider children's growth and development, identify individual parents and child personality and characteristics, and children who use the facilities interact sufficiently with teachers and are satisfied with it. Based on the explanation above, it is hypothesized that:

H5: There is a significant and positive relationship between empathy and parents' satisfaction.

\section{Research Methodology}

The sampling frame used in this study was from the latest population and housing census that was conducted by the Department of Statistics Malaysia (Sarawak Population, 2019). Kuching city was chosen as the research location due to a high concentration of population in Sarawak state. With a population of 617887 in this city, the sample size of 400 with a confidence level of $95 \%$ was calculated using Slovin's formula. By implementing convenience sampling, the parents whose children are between the age of four to six-year-old who enroll in a licensed private kindergarten in Kuching were treated as the most suitable person to participate in the survey. The questionnaire comprises three sections - two of which were tested using a Likert scale i.e. service quality and parents' satisfaction were tested using a Likert scale. The scale for service quality (tangibles, reliability, responsiveness, assurance, and empathy) describes the level of respondent' agreement while the scale on parents' satisfaction represents the level of satisfaction. Lastly, the parents' background section was designed to collect demographic information. This study conducted a self-administered survey to encourage the respondents at their own convenience to complete the questionnaire. The distribution of the questionnaire was carried out within six months. For its accuracy and totality of the responses, a direct approach has been chosen (Brinkman, 2009).

\section{Data Analysis and Findings}

This section presents the results of statistical analysis that have been conducted to test the hypotheses. The procedures and results will be discussed in detail in this section.

\section{Demographics Profiles}

There were 64.3 percent female and 35.8 percent male participated in the survey. Most of them were between 31 to 40 years old $(58.5 \%)$. The analysis showed that the majority of the respondents have up to tertiary education qualifications, including bachelor's degree or professional (34.5\%), diploma (28.8\%), and postgraduate (6.5) meanwhile, $30.3 \%$ of respondents attended secondary school. From a total of 400 respondents, $58.0 \%$ pay between RM151 to RM300, $24.0 \%$ pay RM601 and above, $11.0 \%$ pay RM451 to RM600, and $7.0 \%$ pay RM301 to RM450 for kindergarten's monthly fee. 
Reliability

Reliability test in Table 1 measures 30 items which are Reliability (0.922), Tangibles (0.895), Responsiveness (0.912), Assurance (0.905), Empathy (0.896) and Parents' Satisfaction (0.909). Of the six dimensions in Table 1, the Cronbach alpha is considered acceptable as all are above 0.7 (Sekaran, 2000).

Table 1: Results of Reliability Test

\begin{tabular}{lcc}
\hline Dimension & No. of items & Cronbach's Alpha \\
\hline Reliability & 6 & 0.922 \\
Tangibles & 7 & 0.895 \\
Responsiveness & 5 & 0.912 \\
Assurance & 4 & 0.905 \\
Empathy & 4 & 0.896 \\
Parents' Satisfaction & 4 & 0.909 \\
\hline
\end{tabular}

\section{Correlation}

Based on the Pearson correlation analysis between independent variables i.e. reliability, tangibles, responsiveness, assurance, and empathy and dependent variable i.e. parents' satisfaction, Table 2 shows that all the independent variables are significantly correlated with the dependent variable at 0.000 significance level. 0.000 significance level. The strength of the correlation coefficient refers to the Hair (2003) rule of thumb. The range of coefficients from 0.81 to 1.00 is very high, from 0.61 to 0.80 is strong, from 0.41 to 0.60 is medium, from 0.21 to 0.40 is weak with low correlation, and from 0.00 to 0.20 is very weak to no relationship at all.

The correlation coefficient indicates that there was a strong positive correlation between reliability and parents' satisfaction $(r=0.744, p=0.000)$, tangibles and parents' satisfaction $(r=$ 0.763, $p=0.000)$, responsiveness and parents' satisfaction ( $r=0.777, p=0.000)$, assurance and parents' satisfaction $(r=0.775, p=0.000)$, as well as empathy and parents' satisfaction $(r=0.803$, $p=0.000)$. 
INTERNATIONAL JOURNAL OF ACADEMIC RESEARCH ECONOMICS AND MANAGEMENT SCIENCES

Vol. 8, No. 4, 2019, E-ISSN: 2226-3624 ㄷ 2019 HRMARS

Table 2: Results of Pearson's Correlation Coefficients Analysis

\begin{tabular}{|c|c|c|c|c|c|c|c|}
\hline & & $\begin{array}{l}\text { Reliabilit } \\
\text { y }\end{array}$ & Tangibles & $\begin{array}{l}\text { Responsive } \\
\text { ness }\end{array}$ & $\begin{array}{l}\text { Assuranc } \\
\text { e }\end{array}$ & $\begin{array}{l}\text { Empath } \\
\text { y }\end{array}$ & $\begin{array}{l}\text { Parents' } \\
\text { Satisfacti } \\
\text { on }\end{array}$ \\
\hline \multirow[t]{2}{*}{ Reliability } & $r$ & 1 & $.816^{* *}$ & $.821^{* *}$ & $.806^{* *}$ & $.787^{* *}$ & $.744^{* *}$ \\
\hline & Sig. & & .000 & .000 & .000 & .000 & .000 \\
\hline \multirow[t]{2}{*}{ Tangibles } & $r$ & $.816^{* *}$ & 1 & $.831^{* *}$ & $.794^{* *}$ & $.807^{* *}$ & $.763^{* *}$ \\
\hline & Sig. & .000 & & .000 & .000 & .000 & .000 \\
\hline Responsivn & $r$ & $.821^{* *}$ & $.831^{* *}$ & 1 & $.847^{* *}$ & $.813^{* *}$ & $.777^{* *}$ \\
\hline ess & Sig. & .000 & .000 & & .000 & .000 & .000 \\
\hline \multirow[t]{2}{*}{ Assurance } & $r$ & $.806^{* *}$ & $.794^{* *}$ & $.847^{* *}$ & 1 & $.824^{* *}$ & $.775^{* *}$ \\
\hline & Sig. & .000 & .000 & .000 & & .000 & .000 \\
\hline \multirow[t]{2}{*}{ Empathy } & $r$ & $.787^{* *}$ & $.807^{* *}$ & $.813^{* *}$ & $.824^{* *}$ & 1 & $.803^{* *}$ \\
\hline & Sig. & .000 & .000 & .000 & .000 & & .000 \\
\hline Parents' & $r$ & $.744^{* *}$ & $.763^{* *}$ & $.777^{* *}$ & $.775^{* *}$ & $.803^{* *}$ & 1 \\
\hline Satisfaction & Sig. & .000 & .000 & .000 & .000 & .000 & \\
\hline
\end{tabular}

$* *$. Correlation is significant at the 0.01 level (1-tailed).

Multiple Regression Analysis

Multiple regression analysis in Table 3 provides information on the service quality dimensions that affects parents' satisfaction. The results in Table 3 explain that reliability (sig. $=0.044, p<$ 0.05 ), tangibles (sig. $=0.016, p<0.05$ ), responsiveness (sig. $=0.000, p<0.05$ ), assurance (sig. $=$ $0.009, p<0.05$ ), and empathy (sig. $=0.000, p<0.05$ ) are significant in the observation of the influence of service quality on parents' satisfaction. The beta weight shows that responsiveness $(\beta=0.307)$ is perceived to have the most influential dimension on the parents' satisfaction, while empathy $(\beta=0.255)$, assurance $(\beta=0.154)$, as well as tangibles $(\beta=0.122)$ have a lesser effect on parents' satisfaction. Lastly, reliability $(\beta=0.111)$ is observed to have the least influence on parents' satisfaction. 
INTERNATIONAL JOURNAL OF ACADEMIC RESEARCH ECONOMICS AND MANAGEMENT SCIENCES Vol. 8, No. 4, 2019, E-ISSN: 2226-3624 ㄷ 2019 HRMARS

Table 3: Results of Multiple Regression Analysis

\begin{tabular}{|c|c|c|c|c|c|c|}
\hline \multirow{2}{*}{\multicolumn{2}{|c|}{ Model }} & \multicolumn{2}{|c|}{$\begin{array}{c}\text { Unstandardized } \\
\text { Coefficients }\end{array}$} & \multirow{2}{*}{$\begin{array}{c}\text { Standardized } \\
\text { Coefficients }\end{array}$} & \multirow[b]{2}{*}{$\mathbf{t}$} & \multirow[b]{2}{*}{ Sig. } \\
\hline & & B & Std. Error & & & \\
\hline \multirow[t]{6}{*}{1} & (Constant) & 3.642 & .315 & & 11.571 & .000 \\
\hline & Reliability & .068 & .034 & .111 & 2.019 & .044 \\
\hline & Tangibles & .062 & .026 & .122 & 2.410 & .016 \\
\hline & Responsiveness & .216 & .044 & .307 & 4.920 & .000 \\
\hline & Assurance & .132 & .051 & .154 & 2.608 & .009 \\
\hline & Empathy & .221 & .044 & .255 & 5.010 & .000 \\
\hline
\end{tabular}

a. Dependent Variable: Parents' Satisfaction

Table 4 illustrates coefficient ( $R$ Square) is 0.810 which means that $81.0 \%$ of the variance in parents' satisfaction can be explained from the five independent variables labeled as reliability, tangibles, responsiveness, assurance, and empathy.

Table 4: Model Summary

\begin{tabular}{l|cccc} 
Model & $\mathbf{R}$ & R Square & Adjusted R Square & $\begin{array}{c}\text { Std. Error of the } \\
\text { Estimate }\end{array}$ \\
\hline 1 & $.900^{\mathrm{a}}$ & .810 & .807 & 1.598 \\
\hline
\end{tabular}

a. Predictors: (Constant), Reliability, Tangibles, Responsiveness, Assurance, and Empathy

b. Dependent Variable: Parents' Satisfaction

The ANOVA result in Table 5 presents the model is statistically significant (sig. $=0.000$, $p<0.05$ ) with F-value 335.593. The probability value of 0.000 describes that out of 1000 , there is no chance that the correlation coefficient is zero.

Table 5: Results of ANOVA

\begin{tabular}{llccccc}
\hline Model & & Sum of Squares & df & Mean Square & F & Sig. \\
\hline 1 & Regression & 4286.963 & 5 & 857.393 & 335.593 & $.000^{\mathrm{b}}$ \\
& Residual & 1006.615 & 394 & 2.555 & & \\
& Total & 5293.577 & 399 & & & \\
\hline
\end{tabular}

a. Dependent Variable: Parents' Satisfaction

b. Predictors: (Constant), Reliability, Tangibles, Responsiveness, Assurance, and Empathy

Hypothesis Testing

Based on the summary of hypothesis testing in Table 6, it can be decided that all the five hypotheses were supported. 
INTERNATIONAL JOURNAL OF ACADEMIC RESEARCH ECONOMICS AND MANAGEMENT SCIENCES Vol. 8, No. 4, 2019, E-ISSN: 2226-3624 C 2019 HRMARS

Table 6: Summary of Hypothesis Testing

\begin{tabular}{lll}
\hline & Hypothesis Statement & Conclusion \\
\hline $\mathrm{H}_{1}$ : Reliability has a positive and significant relationship with parents' & Supported \\
satisfaction. &
\end{tabular}

$\mathrm{H}_{2}$ : Tangibles has a positive and significant relationship with parents' Supported satisfaction.

$\mathrm{H}_{3}$ : Responsiveness has a positive and significant relationship with parents' Supported satisfaction.

$\mathrm{H}_{4}$ : Assurance has a positive and significant relationship with parents' Supported satisfaction.

$\mathrm{H}_{5}$ : Empathy has a positive and significant relationship with parents' Supported satisfaction.

\section{Discussion}

SERVQUAL is a well-established instrument to evaluate service quality and customer satisfaction. Five dimensions of service quality namely reliability, tangibles, responsiveness, assurance, and empathy were examined on their influence on parents' satisfaction. The result is consistent with the finding in Chen and Childhood (2016) and Incesu and Asikgil (2012), that is the reliability is significantly linked to the parents' satisfaction. It is observed in the findings that the parents value reliability the most as the private kindergartens are able to provide healthy and safe meals, promise things can complete on schedule, help children to resolve problems and faithfully inform parents about education information. As mentioned in Kim (2014), the ability to respond to emergency situations requires the improvement of the reliable service to raise the satisfaction level. Next, this finding supports an earlier study in which tangibles has a significant and positive relationship on parents' satisfaction (Incesu \& Asikgil, 2012). Parasuraman et al. (1988) explained that the presence of physical facilities and personal appearance are tangibles. Parents would be satisfied with the service if the service providers are able to improve their physical attributes and communication materials, including the appearance of building, teachinglearning materials, and the environment. In line with Zakaria et al. (2010), tangibles dimension a significant association on customer satisfaction particularly on the cleanliness and physical facilities. Hence, kindergarten should upgrade their facilities such as indoor play equipment and teaching aids, as well as reinforce the cleanliness in order to satisfy the parents. Following, responsiveness is strongly related to parents' satisfaction (Vaz \& Mansori, 2013). In the education sector, Mosahab and Mahamad (2010) pointed out that the students view the responsiveness dimension as the most critical dimension. Responsiveness reflects the ability of the school to provide the customer with prompt and individualized service, attention to individual needs and parents' requests to satisfy them. Then, this study reveals that assurance has a significant and positive relationship with parents' satisfaction. Assurance refers to the kindness, knowledge, ability of the employees to persuade confidence and trust (Parasuraman et al., 1988). The finding is consistent with Incesu and Asikgil (2012) who found out that assurance has a significant and 
positive influence on parents' satisfaction. The findings highpoint on the importance of courtesy and trust in order to gain a higher satisfaction level. Chen and Childhood (2016) highlighted that kindergartens that are able to provide a good learning environment, extraordinary teacher quality and the ability to improve responses to the crisis would lead to satisfaction. Apart from that, this study also discovers empathy has a significant and positive relationship on parents' satisfaction. This study lends support to work in Incesu and Asikgil (2012); Darwish (2016) as well as Vaz and Masori (2013) who emphasis to personal care and personalized attention are the reasons that influence parents' satisfaction level. Parents believe the service provider is trying to individualize services based on their personal needs. Overall, by examining the kindergartens' overall performance in service quality would indicate the areas of strength and a room for future improvement.

The results of the multiple regression analysis show that all SERVQUAL dimensions are significant to improve parents' satisfaction. Each SERVQUAL dimension has varying degrees of importance in influencing parents' satisfaction. Based on the results discussed in the previous chapter, responsiveness is the most dominant factor in improving parents' satisfaction. Hence, private kindergartens should focus on improving the responsiveness of their services. Responsiveness is an important prerequisite for achieving the quality of customer satisfaction, and lack of service is the main cause of dissatisfaction (Parasuraman et al., 1991). Not all parents have the time or ability to actively participate in the daily progress of their child's school. Hence, it is crucial to maintain continuous communication with parents. Teachers play an important role as they should regularly tell and ask parents in order to understand each child's situation. Teachers should promptly respond to children's needs and make efforts to address them.

\section{Conclusion}

In conclusion, other than five dimensions that make up the SERVQUAL, there are other factors that may influence parents' satisfaction. Future studies may examine parents' satisfaction level considering factors such as the price level and parents' pre-perception towards the service quality of private kindergarten prior to experiencing the services. The research can be extended by measuring the service quality of public kindergarten. The findings on public sector quality delivery are worth comparing to see the gap between the private and public kindergarten.

\section{Acknowledgment}

This paper is funded by grant scheme F01/SpMYRA/1684/2018 and supported by the Universiti Malaysia Sarawak (UNIMAS).

\section{References}

Al-Borie, H. M., and Damanhuri, A. M. S. (2013). Patients' satisfaction of service quality in Saudi hospitals: a SERVQUAL analysis. International Journal Healthcare Quality Assurance, 26(1), 20-30.

Al-Tamimi, H. A. H., \& Al-Amiri, A. (2003). Analysing service quality in the UAE Islamic banks. Journal of Financial Services Marketing, 8(2), 119-132.

Amin, M., \& Isa, Z. (2008). An examination of the relationship between service quality perception and customer satisfaction: A SEM approach towards Malaysian Islamic banking. 
INTERNATIONAL JOURNAL OF ACADEMIC RESEARCH ECONOMICS AND MANAGEMENT SCIENCES

Vol. 8, No. 4, 2019, E-ISSN: 2226-3624 ㄷ 2019 HRMARS

International Journal of Islamic and Middle Eastern Finance and Management, 1(3), 191209.

Are private schools better than public ones? (November 23, 2015). New Straits Times. Retrieved December 21, 2018 from https:/www.nst.com.my/news/2015/11/113362/are-privateschools-better-public-ones

Asubonteng, P., Mccleary, K. J., \& Swan, J. E. (1996). Asubonteng-SERVQUAL revisited, 10(6), 6281.

Baki, B., Basfirinci, S. C., Murat ar, I., \& Cilingir, Z. (2009). An application of integrating SERVQUAL and Kano's model into QFD for logistics services:A case study from Turkey. Asia Pacific Journal of Marketing and Logistics, 21(1), 106-126.

Berry L. L., \& Parasuraman, A. (1991). Marketing Services: Competing throught Quality. The Free Press, New York.

Brinkman, W. (2009). Design of a Questionnaire Instrument. Handbook of Mobile Technology Research Methods, 31-57.

Chen, Y., \& Childhood, E. (2016). IPA Analysis on Service Quality of Pre-schools : Based on PZB Model, 12, 10-19.

Cryer, D., \& Burchinal, M. (1997). Parents as child care consumers. Early Childhood Research Quarterly, 12, 35-58.

Darwish, S. (2016). The Understanding of Probability in the Iraqi Culture. International Journal of Mainstream Social Science: Vol. 5, Nos. 1-2, 11.

Gerpott, T. J., Rams, W., \& Schindler, A. (2001). Customer retention, loyalty, and satisfaction in the German mobile cellular telecommunications market. Telecommunications policy, 25(4), 249-269.

Hair, J. F., Bush, R. P., \& Ortinau, D. J. (2003). Marketing Research: Within a Change Information Environment. Second Edition. London: McGraw-Hill.

Hasan, H. F. A., Ilias, A., Rahman, R. A., \& Razak, M. Z. A. (2009). Service Quality and Student Satisfaction: A Case Study at Private Higher Education Institutions. International Business Research, 1(3), 163-175.

Hill, N., Roche, G., \& Allen, R. (2007). Customer satisfaction: the customer experience through the customer's eyes. The Leadership Factor.

Incesu, G., \& Asikgil, B. (2012). An Evaluation of the Relationship between Service Quality in Primary Education and Parent Satisfaction. International Journal of Business and Management, 7(18).

Kim, E. (2014). Quality Analysis of Child Care Services using SERVQUAL and Study on Factors Effecting Intent to Recommend to Others and to Re-use. Seoul: Korea Institute for Health and Social Affairs.

Kindergarten in Malaysia. (2007). Pre-school Malaysia. Retrieved December 21, 2018 from http://www.pre-schoolmalaysia.com/malaysia-kindergarten.html

Kotler, P., and Amstrong, G. (2012). Principle of Marketing.14th Edition. New Jersey. Published by Prentice Hall.

Kotler, P. and Keller, K. (2006). Marketing Management. 12th Edition, Prentice Hall, Upper Saddle River.

Lin, C. C. (2003). A critical appraisal of customer satisfaction and e-commerce. Managerial Auditing Journal, 18(3), 202-212. 
INTERNATIONAL JOURNAL OF ACADEMIC RESEARCH ECONOMICS AND MANAGEMENT SCIENCES

Vol. 8, No. 4, 2019, E-ISSN: 2226-3624 C 2019 HRMARS

Malaysia keen to adopt system from British Muslim school. (2017). FMT News. Retrieved from December 21, 2018 from

https://www.freemalaysiatoday.com/category/nation/2017/01/25/education-ministerkeen-to-adopt-system-from-uk-school/

Meesala, A., \& Paul, J. (2018). Service quality, consumer satisfaction and loyalty in hospitals: Thinking for the future. Journal of Retailing and Consumer Services, 40(November 2017), 261-269.

Menon, S. (2016). Focus on quality of pre-school learning. The Star Online. Retrieved December 21, 2018 from https://www.thestar.com.my/news/education/2016/03/20/focus-onquality-of-pre-school-learning/

Mosahab, R., \& Mahamad, O. (2010). Comparison of Service Quality Gaps among Teachers and Students as Internal and External Customers. International Journal Of Marketing Studies, 2(2), 13-21.

Murali, S., Pugazhendhi, S., \& Muralidharan, C. (2016). Modelling and Investigating the relationship of after sales service quality with customer satisfaction, retention and loyalty A case study of home appliances business. Journal of Retailing and Consumer Services, 30, 67-83.

Parasuraman, A., Berry, L. L., \& Zeithaml, V. A. (1991). Refinement and reassessment of the SERVQUAL scale. Journal of Retailing, 67(4), 420-450.

Parasuraman, A., Zeithaml, V. A., \& Berry, L. L. (1985). A Conceptual Model Service Its Quality and Implications for Future Research. Research Paper, 49(4), 41-50.

Parasuraman, A., Zeithaml, V., Berry, L. (1988). SERVQUAL: A Multiple-Item Scale for Measuring Consumer Perceptions of Service Quality. Jorunal of Retailing, 64(September 2014), 12-40.

Pre-school. (2018). The Official Portal of Sarawak Government. Retrieved December 21, 2018 from https://www.sarawak.gov.my/web/home/article_view//280/

Sarawak Population (2018). The Official Portal of Sarawak Government. Retrieved December 21, 2018 from https://www.sarawak.gov.my/web/home/article_view/240/175/

Sekaran, U. (2003). Research methods for business: A skill building approach. $4^{\text {th }}$ Edition. New York: John Wiley \& Sons.

Suki, N. M., \& Lian, J. C. C. (2011). Do patients' perceptions exceed their expectations in private healthcare settings? International Journal of Health Care Quality Assurance, 24(1), 42-56.

Vaz, A., \& Mansori, S. (2013). Malaysian private education quality: Application of SERVQUAL model. International Education Studies, 6(4), 164-170.

Vij, S., \& Bedi, H. S. (2016). Are subjective business performance measures justified? International Journal of Productivity and Performance Management, 65(5), 603-621.

Woodhead, M. (1996). In search of the Rainbow: Pathways to Quality in Large Scale

Programmes for Young Disadvantaged Children, The Hague, Bernard van Leer Foundation.

Zakaria, Z., Hussin, H. Z., Batau, M. F. A., \& Zakaria, Z. (2010). Service Quality of Malaysian Public Transports: A Case Study in Malaysia. Cross-cultural Communication, 6(2), 84-92. 